http://garmian.edu.krd

https://doi.org/10.24271/garmian.149

\title{
Determination of iron critical level for main agricultural soils cultivated with wheat (Triticum aestivum L.) in Sulaimani.
}

Akram Othman Esmail*

Sazan Fathi Sharef $* *$

* Professor of Soil Chemistry, Univ. of Salahaddin, Erbil. ** Asst . lecturer at Bakrajo Agricultural Institute

\section{Abstract}

The factorial pot experiment was conducted at Bakrajo Research Station, Ministry of Agriculture and Water Resources, Sulaimani Governorate during the winter growing season from 1/12/2014 to 10/6/2015 for limiting of Fe critical level of soils and wheat plant. The pot factorial experiment included the effect of five levels of Fe- $\operatorname{EDDHA}\left(0,2,4,6\right.$, and 8) $\mathrm{mg} \mathrm{Fe} \mathrm{kg} \mathrm{soil}{ }^{-1}$, soils of 20 locations and their effects on growth, yield and quality of wheat using completely randomized design with 4 replicates. The results indicated to the significant effect of applied Fe levels on grain yield of wheat, the highest mean value (12.66) $\mathrm{g} \mathrm{pot}^{-1}$ was recorded from the second treatment $\left(2 \mathrm{mg} \mathrm{Fe} \mathrm{kg}^{-1}\right)$ which ranged between (3.11-28.02) $\mathrm{g} \mathrm{pot}^{-1}$, while the lowest mean value (11.09) $\mathrm{g} \mathrm{pot}^{-1}$ obtained from the $5^{\text {th }}$ treatment $\left(8 \mathrm{mg} \mathrm{Fe} \mathrm{kg}^{-1}\right)$ which ranged between (3.14-27.62) $\mathrm{g} \mathrm{pot}^{-1}$. The critical level of Fe was determined in wheat using graphic method and statistical method depending on iron concentration in the plant (mg kg ${ }^{-1}$ dry weight) and relative yield the iron which was $\left(50.50 \mathrm{mg} \mathrm{kg}^{-1}\right.$ dry matter. While the critical level of iron in the studied soil was (2.61) $\mathrm{mgkg}^{-1}$ using graphical method and (2.50) $\mathrm{mgkg}^{-1}$ depending on statistical method for the studied soils in Sulaimani governorate.

Key words: Iron critical level, wheat, calcareous soil.

$* *=$ Apart of M.Sc thesis for the $2^{\text {nd }}$ researcher. 


\section{INTRODUCTION:}

Plants grow in soils with limited availability of Fe are not able to accumulate sufficient amounts of $\mathrm{Fe}$ in its edible parts, leading to nutrition disorders (Fe deficiency) in human body that depend on staple

food crops like cereals (White and Broadley, 2009).Iron has many important functions in plant growth and development, such as involvement in the biosynthesis of chlorophyll, respiration, chloroplast development and improves the performance of photosystems. It is an essential part of many enzymes. Iron also participates in the oxidation process that releases energy from sugars and starches and in response of that converting nitrate to ammonium in plant. It plays an essential role in nucleic acid metabolism . The availability of Fe in soils is affected by soil properties such as soil $\mathrm{pH}$, calcium carbonate content, organic matter, accumulation of phosphorus, ion imbalance, soil texture, soil temperature, poor soil aeration, high humidity and soil compaction. Availability of iron and most micronutrient is largely $\mathrm{pH}-$ depended, availability decreases as $\mathrm{pH}$ increase. The lower the $\mathrm{pH}$ value of soil solution, causes the higher availability of soluble Fe. The dominant Fe species in the $\mathrm{pH}$ range of 5.0 to 7.5 is $\mathrm{Fe}(\mathrm{OH})^{2+}$ which decreases 10 -folds for each unit increase in $\mathrm{pH}$ while the activity of $\mathrm{Fe}^{3+}$ decreases 1000 -fold. ( Havlin et al., 2014).

A critical value in the literature is defined as the concentration below which deficiency of specific nutrient occur. Critical values of several plants have been widely published despite the fact that this critical level may not be applicable at different growth stages. Soil Science Society of America defines critical soil test concentration as "The concentration at which $95 \%$ of maximum relative yield is achieved."

Olsen and Carlson (1950), reported that the critical level of Fe extracted by $\mathrm{NH}_{4} \mathrm{OAC}$ was (2.0) $\mathrm{mg} \mathrm{Fe} \mathrm{kg}^{-1}$. The critical level of Fe availability in 35 calcareous soil sample which extracted by DTPA+CaCl $\mathrm{Cl}_{2}$ method was (4.5) $\mathrm{mg} \mathrm{Fe} \mathrm{kg}{ }^{-1}$ (Lindsay and Norvell, 1978). Data indicated that the critical level of Fe which 
extracted by DTPA+NH $\mathrm{NHCO}_{3}$ method for 40 soil sampls in USA was (4.5) mg Fe $\mathrm{kg}^{1}$ (Havlin and Soltanpour, 1981).

Jarallah (2005) reported that the critical Fe level for wheat plant in some calcareous soils was (77.0) $\mathrm{mg} \mathrm{Fe} \mathrm{kg}^{-1}$ dry matter, while the critical rang of Fe for wheat plant was between $46.4-173.9 \mathrm{mg} \mathrm{Fe} \mathrm{kg}^{-1}$. Iron deficiency is likely to occur when Fe content is $50 \mathrm{mg} \mathrm{Fe} \mathrm{kg}^{-1}$, Ahmad et al., (1996). Kumar (2002) reported that the critical limit in wheat plant was $43.52 \mathrm{mg} \mathrm{Fe} \mathrm{kg}^{-1}$. Lindsay and Schwab (1982), reported that the critical limit of $\mathrm{Fe}$ in Soybean was $50 \mathrm{mg} \mathrm{Fe} \mathrm{kg}^{-1}$.).In Kurdistan region there are some studies about nutrient critical level of phosphorus and potassium which were conducted by Shekh bzayni (2005), Hama-Amin (2012) and Khdir (2017).

Since there are little or no studies about iron critical level in soil and plant in Kurdistan region for this reason this study was selected to determine the iron critical level in soil and wheat plant in Sulaimani governorate.

\section{MATERIALS AND METHODS:}

Soil samples were collected from twenty different locations in Sulaimani governorate as shown in table (1). The samples were taken from soil surface (0-30) cm depth (Halverson, 2001) up on bringing the samples to the laboratory they were air dried, ground and kept until use. Quantitative amount of soil samples were taken for pot experiment, chemical and physical analysis.

Some soil physical and chemical analysis were done on the (2) $\mathrm{mm}$ sieving samples, according to Jackson(1973) .

Available iron for soils was determined by AAS, using (Ammonium BicarbonateDTPA) using $1 M$ ammonium bicarbonate $\left(\mathrm{NH}_{4} \mathrm{HCO}_{3}\right.$, and $0.005 M$ DTPA) extract (Soltanpour and Schwab, 1977). 


\section{-Biological experiment}

The factorial pot experiment was conducted at Bakrajo Research Station, Ministry of Agriculture and Water Resources, Sulaimani Governorate during the winter growing season from 1/12/2014 to $10 / 6 / 2015$ for identifying the critical level of Fe in the studied soil and cultivated wheat. Each pot $35 \mathrm{~cm}$ height, $28 \mathrm{~cm}$ top diameter) was filled with same weight $(13.5 \mathrm{~kg})$ of air dried soil after passing through $(4 \mathrm{~mm})$ sieve. The pot experiment included the effect of five levels of FeEDDHA $\left(0,2,4,6\right.$, and 8) $\mathrm{mg} \mathrm{Fe} \mathrm{kg} \mathrm{soil}{ }^{-1}$,soils of 20 locations and their interactions on growth, yield and quality of wheat. On 1/12/2014, 15 seeds of wheat (Tritium aestivum) were planted in each pot at (5) $\mathrm{cm}$ depth, after germination the plants were thinned to 8 plants per pot. Nitrogen fertilizer as urea was applied at a level of (200) $\mathrm{kg} \mathrm{N} \mathrm{ha}^{-1}$, for all pots to give up amount of nitrogen equivalent to (1.338) $\mathrm{g} \mathrm{N}_{\text {pot }}{ }^{-1}$.On 12/6/2015 the plants were harvested then oven dried at $65 \mathrm{C}^{\circ}$ for 72 hours, then weighted, grounded and stored for chemical analysis which mentioned previously. Wheat straw and seed were analyzed for (Fe) by atomic absorption from the acid digested, values were computed against curves prepared freshly each day. The atomic absorption spectrometer (AAS) PerkinElmer Model 1100B was used.

Determination of iron critical level:

The critical level of Iron in the soil and plant was determined by Cate and Nelson (1965) methods using graphic and statistical methods.

\section{Statistical Analysis:}

In all cases, two-way analyses of variance (ANOVA) using with the help of computer software XLSTAT. Revised Least Significant differences (RLSD. ${ }_{01}$ ) test was used to compare the differences among a means at significant level of $1 \%$, using SAS, (2001). 
Table (1): The studied locations and their position according to GPS.

\begin{tabular}{|c|c|c|}
\hline Soil No & location & GPS coordination \\
\hline 1 & Qlyasan & $35^{\circ} 34^{\prime} 53.6^{\prime \prime} \mathrm{N} 45^{\circ} 21^{\prime} 59.0^{\prime \prime} \mathrm{E}$ \\
\hline 2 & Bazyan & $35^{\circ} 35^{\prime} 34.6^{\prime \prime} \mathrm{N} 45^{\circ} 08^{\prime} 26.9^{\prime \prime} \mathrm{E}$ \\
\hline 3 & Bakrajo & $35^{\circ} 32^{\prime} 52.8^{\prime \prime} \mathrm{N} 45^{\circ} 21^{\prime} 16.6^{\prime \prime} \mathrm{E}$ \\
\hline 4 & Serwan & $35^{\circ} 14^{\prime} 11.9^{\prime \prime} \mathrm{N} 45^{\circ} 56^{\prime} 56.2^{\prime \prime} \mathrm{E}$ \\
\hline 5 & Baynjan & $35^{\circ} 38^{\prime} 30.4^{\prime \prime} \mathrm{N} 45^{\circ} 03^{\prime} 57.4^{\prime \prime} \mathrm{E}$ \\
\hline 6 & Halbja & $35^{\circ} 07^{\prime} 52.1^{\prime \prime} \mathrm{N} 46^{\circ} 02^{\prime} 37.3^{\prime \prime} \mathrm{E}$ \\
\hline 7 & Keli & $35^{\circ} 48^{\prime} 01.9^{\prime \prime} \mathrm{N} 45^{\circ} 27^{\prime} 31.1^{\prime \prime} \mathrm{E}$ \\
\hline 8 & SaidSadiq & $35^{\circ} 23^{\prime} 04.5^{\prime \prime} \mathrm{N} 45^{\circ} 47^{\prime} 22.7^{\prime \prime} \mathrm{E}$ \\
\hline 9 & Kalar & $34^{\circ} 38^{\prime} 59.6^{\prime \prime} \mathrm{N} 45^{\circ} 15^{\prime} 14.6^{\prime \prime} \mathrm{E}$ \\
\hline 10 & Kifri & $34^{\circ} 39^{\prime} 15.9^{\prime \prime} \mathrm{N} 44^{\circ} 55^{\prime} 08.3^{\prime \prime} \mathrm{E}$ \\
\hline 11 & Penjwen & $35^{\circ} 37^{\prime} 37.6^{\prime \prime} \mathrm{N} 45^{\circ} 566^{\prime} 59.4^{\prime \prime} \mathrm{E}$ \\
\hline 12 & Qaldza & $36^{\circ} 13^{\prime} 06.7^{\prime \prime} \mathrm{N} 45^{\circ} 08^{\prime} 58.9^{\prime \prime} \mathrm{E}$ \\
\hline 13 & Ranya & $36^{\circ} 14^{\prime} 00.1^{\prime \prime} \mathrm{N} 44^{\circ} 50^{\prime} 52.6^{\prime \prime} \mathrm{E}$ \\
\hline 14 & Chamchamal & 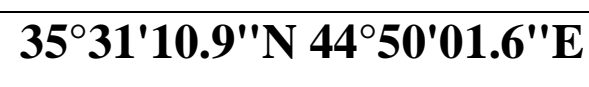 \\
\hline 15 & Darbandekhan & $35^{\circ} 07^{\prime} 23.8^{\prime \prime} \mathrm{N} 45^{\circ} 39^{\prime} 47.9^{\prime \prime} \mathrm{E}$ \\
\hline 16 & Kanipanka & $35^{\circ} 22^{\prime} 46.8^{\prime \prime} \mathrm{N} 45^{\circ} 42^{\prime} 17.1^{\prime \prime} \mathrm{E}$ \\
\hline 17 & Zrgwez & $35^{\circ} 22^{\prime} 30.2^{\prime \prime} \mathrm{N} 45^{\circ} 26^{\prime} 07.2^{\prime \prime} \mathrm{E}$ \\
\hline 18 & Tasloja & $35^{\circ} 37^{\prime} 53.8^{\prime \prime} \mathrm{N} 45^{\circ} 14^{\prime} 40.0^{\prime \prime} \mathrm{E}$ \\
\hline 19 & Dukan & $35^{\circ} 54^{\prime} 32.6^{\prime \prime} \mathrm{N} 45^{\circ} 00^{\prime} 09.9^{\prime \prime} \mathrm{E}$ \\
\hline 20 & Mawat & $35^{\circ} 52^{\prime} 40.5^{\prime \prime} \mathrm{N} 45^{\circ} 26^{\prime} 07.2^{\prime \prime} \mathrm{E}$ \\
\hline
\end{tabular}

\section{RESULTS AND DISSCUION:}

Data of the most important properties of the investigated soils were shown in table (2) and (3); it reveals that the soils included various textures, from clay soil to silty loam. The $\mathrm{pH}$ value was ranged from 7.24 to 8.36 with mean value of (7.90). 
This means that all the tested soils were slightly alkaline. The electrical conductivity (EC) of the studied soil was between $(0.55$ and 4.3$) \mathrm{dSm}^{-1}$, with mean value of 1.038, which indicates that the soils are non-saline, except Zrgwez location which is saline soil. Cation exchange capacity (CEC) was ranged between (10.05 38.61) $\mathrm{cmol}_{\mathrm{C}} \mathrm{kg}^{-1}$ soil, it means they are differing in fertility. The amount of organic matter in the soils was ranged from (7.00 to 38.70$) \mathrm{g} \mathrm{kg}^{-1}$, it mean that most of the soil have low organic matter content, (Baruah and Barthakur,1999) Active lime was ranged between $(8.40-67.20) \mathrm{g} \mathrm{kg}^{-1}$. The total $\mathrm{CaCO}_{3}$ was between $(31.70-325.30)$ $\mathrm{g} \mathrm{kg}^{-1}$, It means most of the soils are very calcareous (contains more than $100 \mathrm{~g} \mathrm{~kg}^{-1}$ $\mathrm{CaCO}_{3}$ and soil No 8 and 11 are slightly calcareous (contain less than $50 \mathrm{~g} \mathrm{~kg}^{-1}$ $\mathrm{CaCO}_{3}$ ), (Hodgason, 1976).

Table (3) shows that the concentration of $\mathrm{Ca}^{++}$in most of the studied soil were more than $\mathrm{Mg}^{++}$concentration, except locations(SaidSadq, Qaladza, Ranya and Zrgwez) which the concentration of $\mathrm{Mg}^{++}$were more than $\mathrm{Ca}^{++}$, this may be due to the dominate of dolomite mineral in these locations. At the same time the concentration of $\mathrm{Na}^{+}$in the studied soil were more than $\mathrm{K}^{+}$. The soluble cations were determined for this reason the $\mathrm{Mg}$ concentration of Penjwen and Qaladza was similar in spite of existing serpentine clay mineral in Penjwen soil which regards a source of $\mathrm{Mg}$ but it not dissolve in water but it dissolve in strong acid extracts. The high concentration of $\mathrm{HCO}_{3}^{-}$was recorded in10 locations, and the high concentration of $\mathrm{Cl}^{-}$were obtained in Keli locations, while the highest concentration of $\mathrm{SO}_{4}^{-}$was recorded Bakrajo location (table, 3), this may be due to the reasons mentioned before. The iron concentration in the studied soils was ranged between (1.66-3.96) $\mathrm{mg} \mathrm{Fe} \mathrm{kg}^{-1}$ (table,3) which was less than the adequate amount (4) $\mathrm{mg} \mathrm{Fe} \mathrm{kg}^{-1}$ (Soltanpour and Schwab,1977). 
Table (2): Some physical and chemical characteristics of studied soils.*

\begin{tabular}{|c|c|c|c|c|c|c|c|c|c|}
\hline \multirow{2}{*}{ } & \multirow{2}{*}{ 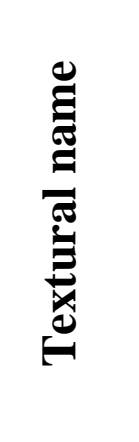 } & \multirow{2}{*}{ 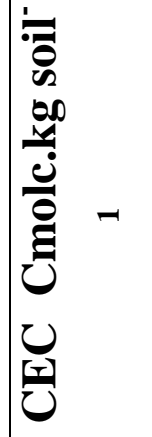 } & \multirow{2}{*}{ بْ } & \multirow{2}{*}{$\frac{1}{3}$} & \multirow{2}{*}{$\overline{2}$} & \multirow{2}{*}{ טئ } & \multirow{2}{*}{ 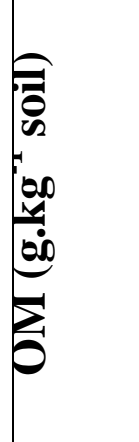 } & \multicolumn{2}{|c|}{$\begin{array}{c}\mathrm{ECaCO}_{3} \\
\mathrm{~g} \mathrm{~kg}^{-1} \text { soil }\end{array}$} \\
\hline & & & & & & & & $\begin{array}{c}\text { Activ } \\
\qquad e\end{array}$ & Total \\
\hline 1 & Clay & 31.38 & 34.50 & $\begin{array}{c}20.7 \\
3\end{array}$ & $\begin{array}{c}7.7 \\
0\end{array}$ & 0.86 & $\begin{array}{c}22.7 \\
0\end{array}$ & 61.60 & 214.20 \\
\hline 2 & $\begin{array}{l}\text { Silt } \\
\text { loam }\end{array}$ & 17.97 & 24.50 & $\begin{array}{c}15.2 \\
3\end{array}$ & $\begin{array}{c}8.0 \\
5\end{array}$ & 1.05 & $\begin{array}{c}24.8 \\
0\end{array}$ & 67.20 & 198.30 \\
\hline 3 & Clay & 32.78 & 33.78 & $\begin{array}{c}24.4 \\
9\end{array}$ & $\begin{array}{c}8.2 \\
6\end{array}$ & 0.55 & $\begin{array}{c}19.4 \\
0\end{array}$ & 67.20 & 253.90 \\
\hline 4 & Clay & 35.01 & 34.46 & $\begin{array}{c}20.3 \\
4\end{array}$ & $\begin{array}{c}7.7 \\
2\end{array}$ & 0.86 & 8.60 & 36.40 & 202.30 \\
\hline 5 & Clay & 32.44 & 33.74 & $\begin{array}{c}24.3 \\
7\end{array}$ & $\begin{array}{c}8.0 \\
8\end{array}$ & 1.36 & $\begin{array}{c}11.5 \\
0\end{array}$ & 56.00 & 325.30 \\
\hline 5 & Clay & 28.87 & 30.08 & $\begin{array}{c}18.9 \\
5\end{array}$ & $\begin{array}{c}7.8 \\
0\end{array}$ & 0.87 & $\begin{array}{c}24.1 \\
0\end{array}$ & 61.60 & 190.40 \\
\hline 7 & $\begin{array}{l}\text { Silt } \\
\text { loam }\end{array}$ & 10.05 & 22.64 & 9.32 & $\begin{array}{c}8.1 \\
7\end{array}$ & 0.60 & 7.00 & 8.40 & 87.30 \\
\hline 8 & Clay & 38.61 & 38.90 & $\begin{array}{c}28.1 \\
6\end{array}$ & $\begin{array}{c}7.6 \\
8\end{array}$ & 0.77 & $\begin{array}{c}26.9 \\
0\end{array}$ & 14.00 & 31.70 \\
\hline 9 & Loam & 12.40 & 21.98 & $\begin{array}{c}12.6 \\
2\end{array}$ & $\begin{array}{c}7.9 \\
8\end{array}$ & 0.95 & 9.10 & 28.00 & 313.40 \\
\hline 10 & $\begin{array}{l}\text { Clay } \\
\text { loam }\end{array}$ & 19.71 & 27.55 & $\begin{array}{c}17.2 \\
1\end{array}$ & $\begin{array}{c}7.5 \\
6\end{array}$ & 1.27 & 9.20 & 47.60 & 261.80 \\
\hline
\end{tabular}




\begin{tabular}{|c|c|c|c|c|c|c|c|c|c|}
\hline 11 & $\begin{array}{l}\text { Clay } \\
\text { loam }\end{array}$ & 22.40 & 26.84 & $\begin{array}{c}18.7 \\
6\end{array}$ & $\begin{array}{c}8.3 \\
6\end{array}$ & 0.63 & $\begin{array}{c}18.0 \\
0\end{array}$ & 14.00 & 119.00 \\
\hline 12 & Clay & 36.45 & 35.72 & $\begin{array}{c}25.8 \\
8\end{array}$ & $\begin{array}{c}7.8 \\
5\end{array}$ & 0.59 & $\begin{array}{c}27.1 \\
0\end{array}$ & 50.40 & 162.60 \\
\hline 13 & Clay & $\mathbf{3 4 . 3 7}$ & 36.24 & $\begin{array}{c}26.1 \\
8\end{array}$ & $\begin{array}{c}7.9 \\
5\end{array}$ & 0.69 & $\begin{array}{c}16.3 \\
0\end{array}$ & 30.80 & 119.00 \\
\hline 14 & Clay & 28.86 & 24.11 & $\begin{array}{c}23.6 \\
1\end{array}$ & $\begin{array}{c}8.0 \\
4\end{array}$ & 0.89 & $\begin{array}{c}12.3 \\
0\end{array}$ & 61.60 & 265.80 \\
\hline 15 & $\begin{array}{l}\text { Clay } \\
\text { loam }\end{array}$ & 24.17 & 28.75 & $\begin{array}{c}21.3 \\
6\end{array}$ & $\begin{array}{c}8.0 \\
3\end{array}$ & 0.73 & 9.30 & 39.20 & 249.90 \\
\hline 16 & Clay & 36.50 & 38.27 & $\begin{array}{c}26.0 \\
9\end{array}$ & $\begin{array}{c}7.8 \\
6\end{array}$ & 1.22 & $\begin{array}{c}29.8 \\
0\end{array}$ & 30.80 & 31.70 \\
\hline 17 & $\begin{array}{l}\text { Clay } \\
\text { loam }\end{array}$ & 20.52 & 24.85 & $\begin{array}{c}14.9 \\
1\end{array}$ & $\begin{array}{c}7.2 \\
4\end{array}$ & 4.30 & $\begin{array}{c}16.6 \\
0\end{array}$ & 42.00 & 91.20 \\
\hline 18 & Clay & 33.97 & 32.78 & $\begin{array}{c}20.3 \\
4\end{array}$ & $\begin{array}{c}7.6 \\
9\end{array}$ & 0.98 & $\begin{array}{c}38.7 \\
0\end{array}$ & 39.20 & 126.90 \\
\hline 19 & $\begin{array}{l}\text { Clay } \\
\text { loam }\end{array}$ & 24.57 & 28.32 & $\begin{array}{c}21.5 \\
5\end{array}$ & $\begin{array}{c}7.9 \\
6\end{array}$ & 0.90 & $\begin{array}{c}11.6 \\
0\end{array}$ & 44.80 & 218.20 \\
\hline 20 & Clay & 32.27 & 37.06 & $\begin{array}{c}23.8 \\
0\end{array}$ & $\begin{array}{c}8.0 \\
4\end{array}$ & 0.69 & $\begin{array}{c}24.2 \\
0\end{array}$ & 16.80 & 79.00 \\
\hline
\end{tabular}


Table (3): Some soluble cations and anions in the studied soil samples collected from different locations in Sulaimani, IKR. *

\begin{tabular}{|c|c|c|c|c|c|c|c|c|c|}
\hline \multirow{2}{*}{. } & $\mathrm{Ca} 2+$ & $\mathrm{Mg} 2+$ & $\mathrm{K}+$ & $\mathrm{Na}+$ & $\mathrm{Cl}-$ & $\mathrm{HCO}_{3}^{-}$ & $\mathrm{CO}_{3}^{-}$ & $\mathrm{SO}_{4}=$ & $\begin{array}{c}\mathrm{Fe}^{2+} \\
\mathrm{mg} \mathrm{kg}^{-1}\end{array}$ \\
\hline & $\operatorname{mmol}_{\mathrm{c}} \mathrm{L}^{-1}$ & & & & & & & & \\
\hline 1 & 5.80 & 2.60 & 0.27 & 0.93 & 3.40 & 3.70 & trace & 2.50 & 3.09 \\
\hline 2 & 5.00 & 3.40 & 0.89 & 2.87 & 4.20 & 3.10 & 0.80 & 4.06 & 2.18 \\
\hline 3 & 3.60 & 0.80 & 0.14 & 1.41 & 1.80 & 1.30 & trace & 2.85 & 2.74 \\
\hline 4 & 5.20 & 2.80 & 0.14 & 1.66 & 3.20 & 4.00 & trace & 2.59 & 3.68 \\
\hline 5 & 6.80 & 3.60 & 0.27 & 2.79 & 8.60 & 2.90 & 0.80 & 1.16 & 2.15 \\
\hline 6 & 6.60 & 1.20 & 0.27 & 0.97 & 3.00 & 2.50 & 1.20 & 2.34 & 2.42 \\
\hline 7 & 4.20 & 1.20 & 0.14 & 0.93 & 1.60 & 2.70 & trace & 2.17 & 1.70 \\
\hline 8 & 3.80 & 4.20 & 0.23 & 1.25 & 2.80 & 4.50 & trace & 2.18 & 2.79 \\
\hline 9 & 5.60 & 3.20 & 0.62 & 1.13 & 2.20 & 5.30 & trace & 3.05 & 2.96 \\
\hline 10 & 8.00 & 5.20 & 0.37 & 2.22 & 3.00 & 7.10 & trace & 5.69 & 2.12 \\
\hline 11 & 3.20 & 3.20 & 0.18 & 0.81 & 2.40 & 1.90 & 0.80 & 2.29 & 1.80 \\
\hline 12 & 3.00 & 3.20 & 0.09 & 0.69 & 2.60 & 2.50 & trace & 1.88 & 2.51 \\
\hline 13 & 4.00 & 4.60 & 0.30 & 0.69 & 3.40 & 0.90 & trace & 5.28 & 2.83 \\
\hline 14 & 6.00 & 3.60 & 0.27 & 1.21 & 1.60 & 5.70 & trace & 3.79 & 2.13 \\
\hline 15 & 3.80 & 2.20 & 0.25 & 1.57 & 3.00 & 1.70 & trace & 3.13 & 1.93 \\
\hline 16 & 9.80 & 4.60 & 0.21 & 1.49 & 3.00 & 9.70 & trace & 3.40 & 2.98 \\
\hline 17 & 3.60 & 9.80 & 0.55 & 1.33 & 2.40 & 27.90 & trace & 17.38 & 1.66 \\
\hline 18 & 8.00 & 2.60 & 0.37 & 1.13 & 3.70 & 5.10 & trace & 3.30 & 3.96 \\
\hline 19 & 6.40 & 2.20 & 0.25 & 1.17 & 4.00 & 3.90 & 0.80 & 1.32 & 2.26 \\
\hline 20 & 3.80 & 3.20 & 0.14 & 0.93 & 2.80 & 1.90 & 1.20 & 2.17 & 2.12 \\
\hline
\end{tabular}

- 1=Qlyasan 2= Bazyan 3= Bakrajo 4= Serwan 5= Baynjan 6=Halbja 7=Keli 8=SaidSadiq 9= Kalar 10= Kifri 11= Penjwen 12= Qaldza 13= Ranya 14=Chamchamal 15=Darbandekhan 16= Kanipanka $17=$ Zrgwez $18=$ Tasloja $19=$ Dukan $20=$ Mawat 


\section{Effect of iron levels, soil locations and their interactions on wheat grain yield and relative yield \%(R.Y\%):}

Table (4) indicate the significant effect of applied Fe levels on grain yield of wheat (with the RLSD .01 value of 6.29), the highest mean value (12.66) $\mathrm{g} \mathrm{pot}^{-1}$

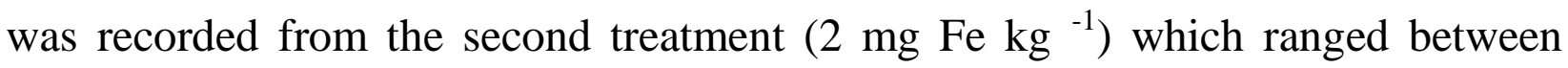
(3.11-28.02) $\mathrm{g} \mathrm{pot}^{-1}$, while the lowest mean value (11.09) $\mathrm{g} \mathrm{pot}^{-1}$ obtained from the $5^{\text {th }}$ treatment $\left(8 \mathrm{mg} \mathrm{Fe} \mathrm{kg}^{-1}\right.$ ) which ranged between (3.14-27.62) $\mathrm{g} \mathrm{pot}^{-1}$. Similar results were obtained by Al-Mustafa et al., (2001). The result indicates that increasing Fe fertilization to certain level is necessary, which caused increase in grain yield of wheat this refers to wheat requirement for Fe fertilization to certain level after that its application may has negative effect. These results agree with those found by Mohsin, (2013).

Table (4) shows that the soil locations has significant effect at $(\mathrm{P} \leq 0.01)$ (with the $\operatorname{RLSD}_{.01}$ value of 2.90) on the grain yield of wheat, the highest mean value of grain yield was (26.29) $\mathrm{g} \mathrm{pot}^{-1}$ recorded from Penjwen location, and the lowest value was (3.35) $\mathrm{g} \mathrm{pot}^{-1}$ recorded from Keli. This may be attributed to the differences in some chemical and physical properties like $\mathrm{OM}, \mathrm{CaCO}_{3}, \mathrm{CEC}$ and soil texture, in soil of Penjwen the $\mathrm{OM}$, active lime, total $\mathrm{CaCO}_{3}, \mathrm{CEC}$ were $\left(18 \mathrm{mg} \mathrm{kg}^{-1}\right.$ soil, $14 \mathrm{~g} \mathrm{~kg}^{-1}$ soil,119 $\mathrm{g} \mathrm{kg}^{-1}$ soil, and 22.40 Cmolc.kg soil ${ }^{-1}$ ) respectively, with clay loam texture. While in soil of Keli the OM, active lime, total $\mathrm{CaCO}_{3}, \mathrm{CEC}$ were $(7 \mathrm{mg}$ $\mathrm{kg}^{-1}$ soil, $8.40 \mathrm{~g} \mathrm{~kg}^{-1}$ soil, $87.30 \mathrm{~g} \mathrm{~kg}^{-1}$ soil, and 10.05 Cmolc.kg soil ${ }^{-1}$ ) respectively with silty loam texture. The interaction between Fe levels and soil locations was significantly affected on grain yield of wheat at $(\mathrm{P} \leq 0.01)$ with the RLSD.01 value of 12.50), the highest value of grain yield (29.08) $\mathrm{g} \mathrm{pot}^{1}$ was recorded from treatment combination of Kanipanka lactation and control $\left(\mathrm{Fe}_{0}\right)$ while the lowest value (2.61) $\mathrm{g} \mathrm{pot}^{-1}$ was recorded from treatment combination Keli 
Table (4): Interaction effect of locations and iron levels on wheat yield.

\begin{tabular}{|c|c|c|c|c|c|c|c|}
\hline \multirow[t]{2}{*}{ Soil locations } & \multicolumn{5}{|c|}{ Levels of applied $\mathrm{Fe}\left(\mathrm{mg} \mathrm{Fe} \mathrm{kg}^{-1}\right.$ soil $)$} & \multirow{2}{*}{$\begin{array}{c}\text { Yield } \\
\left(\text { g.pot }^{-1}\right)\end{array}$} & \multirow[t]{2}{*}{ R.Y\% } \\
\hline & $\mathrm{Fe} 0$ & $\mathrm{Fe} 2$ & $\mathrm{Fe} 4$ & Fe6 & $\mathrm{Fe} 8$ & & \\
\hline Qlyasan & 13.45 & 9.94 & 8.68 & 10.99 & 9.78 & 10.50 & 39.93 \\
\hline Bazyan & 16.97 & 16.78 & 10.61 & 17.26 & 18.80 & 16.08 & 61.16 \\
\hline Bakrajo & 13.97 & 11.45 & 12.03 & 14.90 & 12.57 & 10.48 & 39.84 \\
\hline Serwan & 4.31 & 8.58 & 12.29 & 15.34 & 11.90 & 10.48 & 39.86 \\
\hline Baynjan & 16.32 & 15.21 & 23.09 & 15.23 & 7.92 & 15.55 & 59.14 \\
\hline Halbja & 9.49 & 12.26 & 8.76 & 10.31 & 8.34 & 9.83 & 37.39 \\
\hline Keli & 2.61 & 3.11 & 4.42 & 3.50 & 3.14 & 3.35 & 12.74 \\
\hline Saidsadq & 17.44 & 17.96 & 11.68 & 19.21 & 17.51 & 16.76 & 63.76 \\
\hline Kalar & 8.08 & 8.66 & 8.13 & 6.77 & 4.64 & 7.25 & 27.57 \\
\hline Kfri & 8.08 & 6.46 & 6.48 & 6.94 & 5.77 & 6.74 & 25.63 \\
\hline Penjwen & 31.10 & 21.55 & 26.33 & 24.87 & 27.62 & 26.29 & 100 \\
\hline Qaldza & 11.52 & 13.52 & 12.26 & 11.45 & 14.72 & 12.69 & 48.26 \\
\hline Ranya & 6.13 & 9.27 & 12.01 & 10.85 & 4.97 & 8.64 & 32.86 \\
\hline Chamchamal & 6.33 & 5.81 & 5.76 & 4.77 & 7.69 & 6.07 & 23.08 \\
\hline Darbandekhan & 10.78 & 8.15 & 10.66 & 6.33 & 5.28 & 8.24 & 31.34 \\
\hline Kanipanka & 29.08 & 28.02 & 11.25 & 20.89 & 15.30 & 20.90 & 79.49 \\
\hline Zrgwez & 10.78 & 8.15 & 10.66 & 6.33 & 5.28 & 8.24 & 31.34 \\
\hline Tasloja & 29.08 & 28.02 & 11.25 & 20.89 & 15.30 & 20.90 & 79.49 \\
\hline Dukan & 7.73 & 17.04 & 7.83 & 11.36 & 10.96 & 10.93 & 41.57 \\
\hline Mawat & 21.14 & 18.46 & 8.77 & 20.89 & 18.94 & 17.04 & 67.09 \\
\hline Mean of $\mathrm{Fe}$ & 63.58 & 62.14 & 63.27 & 73.23 & 64.12 & & \\
\hline
\end{tabular}

location at control. This may be due to individual effect of the studied factors due to the large variation between soils of Keli location and soil of Kanipanka location in physical and chemical properties ( table 2 and 3 ), in additional to the 
combination between the studied factors may created different conditions for plant growth as mentioned by Darwesh and Esmail (2008).

\section{Effect of iron levels, soil locations and their interactions on concentration of iron in wheat grains:}

Table (5) indicated that wheat grain's content of iron was significantly influenced by different level of $\mathrm{Fe}$ application. The highest value of $\mathrm{Fe}$ concentration was (73.23) $\mathrm{mg} \mathrm{Fe} \mathrm{kg}^{-1}$ was recorded from application $6 \mathrm{mg} \mathrm{Fe} \mathrm{kg}^{-1}$ and the lowest value (62.14) $\mathrm{mg} \mathrm{Fe} \mathrm{kg}^{-1}$ was recorded from application (2) $\mathrm{mg} \mathrm{Fe}$ $\mathrm{kg}^{-1}$ this results agree with those reported by Jarallah, (2005).

Table (5) represents the significant effect of soil type at $(\mathrm{P} \leq 0.01)$ on $\mathrm{Fe}$ concentration in grain wheat. The highest value was (164.40) $\mathrm{mg} \mathrm{Fe} \mathrm{kg}^{-1}$ which was recorded from SaidSadq location, while the lowest value (16.26) $\mathrm{mg} \mathrm{Fe} \mathrm{kg}^{-1}$ was recorded from Penjwen location. This wide range of Fe concentration in wheat grain attributed to the difference in grain weight. The mean grain weight value of wheat for SaidSadq location was (16.76) $\mathrm{g} \mathrm{pot}^{-1}$ while in Penjwen location the mean value was (26.29) $\mathrm{g} \mathrm{pot}^{-1}$. It observes that whenever the grain weight of wheat is less but the concentration of Fe was more (dilution effect). This may be due to the difference in iron concentration of the studied soils (table 3). It is stated that Fe content of grain was affected by Fe content of soil, iron concentration in soil of SaidSadq location was (2.79) $\mathrm{mg} \mathrm{kg}^{-1}$, while iron concentration in soil Penjwen location was (1.80) $\mathrm{mg} \mathrm{kg}^{-1}$ accordingly, when the amount of iron increases in soil, the concentration of iron will increases in seeds. (Long et al., 2004).

The interaction between levels of Fe and soil types was affected significantly at $(\mathrm{P} \leq 0.01)$ level on Fe concentration in wheat seeds as shown in table (6). The highest value of $\mathrm{Fe}$ was (184.66) $\mathrm{mg} \mathrm{Fe} \mathrm{kg}^{-1}$ was recorded from combination treatment ( Halbja location at application $8 \mathrm{mg} \mathrm{kg}^{-1}$ ), while the lowest values of $\mathrm{Fe}$ was (7.01) $\mathrm{mg} \mathrm{Fe} \mathrm{kg}^{-1}$ was recorded from treatment combination ( Serwan location

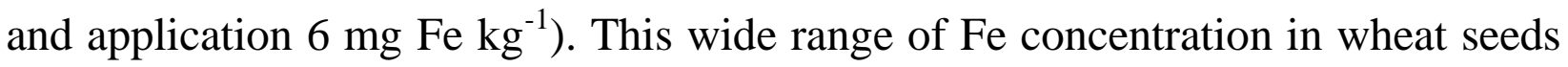


may be due to different $\mathrm{OM}$ and high $\mathrm{CaCO}_{3}$ content or individual effect of the studied factors, OM content in Halbja location was (24.1) $\mathrm{mg} \mathrm{kg}^{-1}$ soil and (8.6) $\mathrm{mg} \mathrm{kg}{ }^{-1}$ soil in soil number $4, \mathrm{CaCO}_{3}$ content in soil number 6 was $(190.40) \mathrm{g} \mathrm{kg}^{-}$ ${ }^{1}$ soil which was less than $\mathrm{CaCO}_{3}$ content in Serwan location which was (202.30) $\mathrm{g}$ $\mathrm{kg}^{-1}$ soil. On the other hand the plants grown in some soils were harvested after storm, which caused decrease in number of leaves then decrease in $\mathrm{Fe}$ concentration due to its determination in stem of wheat plant in state of mixture of leaves and stem (16.63 to 35.19$) \mathrm{mg} \mathrm{kg}^{-1}$ or the ratio between leaves: stem in their treatment was low.

\section{Determination of iron critical level in the studied soils:}

As shown in Figure (1a and b) the critical level for the studied soils, using Cate and Nelson $(1965,1971)$ graphical method by plotting initial concentration of the soluble Iron in soil against relative yield was (2.50) $\mathrm{mg} \mathrm{kg}^{-1}$. The result depending on statistical method was (2.61) $\mathrm{mg} \mathrm{kg-}^{1}$.This result agree with those found by Sims and Johnson (1991). The highest value of coefficient determination was $\left(\mathrm{R}^{2}=0.64\right)$ recorded at concentration $(2.61) \mathrm{mg} \mathrm{kg}^{-1}$.

Table (5): Interaction effect of soils and iron levels on Fe concentration of grains.

\begin{tabular}{|c|c|c|c|c|c|c|}
\hline \multirow{2}{*}{ Soil locations } & \multicolumn{5}{|c|}{ Levels of applied Fe (mg Fe kg ${ }^{-1}$ soil $)$} & Fe \\
\cline { 2 - 6 } & $\mathrm{Fe} 0$ & $\mathrm{Fe} 2$ & $\mathrm{Fe} 4$ & $\mathrm{Fe} 6$ & $\mathrm{Fe} 8$ & mg.g \\
\hline Qlyasan & 75.49 & 36.10 & 16.90 & 22.65 & 10.20 & 32.26 \\
\hline Bazyan & 14.93 & 15.70 & 16.30 & 15.50 & 19.70 & 16.62 \\
\hline Bakrajo & 17.45 & 28.35 & 14.18 & 44.35 & 14.02 & 23.67 \\
\hline Serwan & 8.74 & 16.55 & 10.00 & 7.01 & 133.35 & 35.19 \\
\hline Baynjan & 145.60 & 137.87 & 142.66 & 138.53 & 163.66 & 143.78 \\
\hline Halbja & 144.50 & 149.83 & 164.50 & 177.00 & 184.66 & 164.11 \\
\hline
\end{tabular}




\begin{tabular}{|c|c|c|c|c|c|c|}
\hline Keli & 35.45 & 67.85 & 40.23 & 44.72 & 31.53 & 43.92 \\
\hline Saidsadq & 153.66 & 163.66 & 166.50 & 170.33 & 167.83 & 164.40 \\
\hline Kalar & 148.00 & 159.00 & 165.66 & 169.66 & 162.16 & 160.90 \\
\hline Kfri & 139.51 & 53.81 & 35.40 & 129.50 & 72.22 & 86.09 \\
\hline Penjwen & 22.01 & 18.70 & 16.66 & 12.40 & 11.40 & 16.23 \\
\hline Qaldza & 54.43 & 39.76 & 80.43 & 74.63 & 38.55 & 57.56 \\
\hline Ranya & 74.71 & 35.38 & 32.97 & 73.25 & 24.67 & 48.19 \\
\hline Chamchamal & 9.50 & 26.70 & 24.65 & 36.25 & 47.85 & 29.00 \\
\hline Darbandekhan & 30.70 & 16.05 & 25.83 & 42.79 & 12.83 & 25.64 \\
\hline Kanipanka & 7.15 & 23.75 & 35.75 & 109.15 & 46.70 & 44.50 \\
\hline Zrgwez & 54.51 & 31.89 & 98.39 & 76.34 & 48.25 & 61.87 \\
\hline Tasloja & 44.65 & 38.85 & 81.15 & 36.90 & 28.95 & 46.10 \\
\hline Dukan & 68.22 & 164.42 & 85.17 & 62.43 & 55.33 & 87.11 \\
\hline Mawat & 22.41 & 18.55 & 12.20 & 20.30 & 18.87 & 18.57 \\
\hline Mean of Fe & 63.58 & 62.14 & 63.27 & 73.23 & 64.12 & \\
\hline RLSD.01 & & & & 6.25 & & \\
\hline & & & & & \\
\hline
\end{tabular}

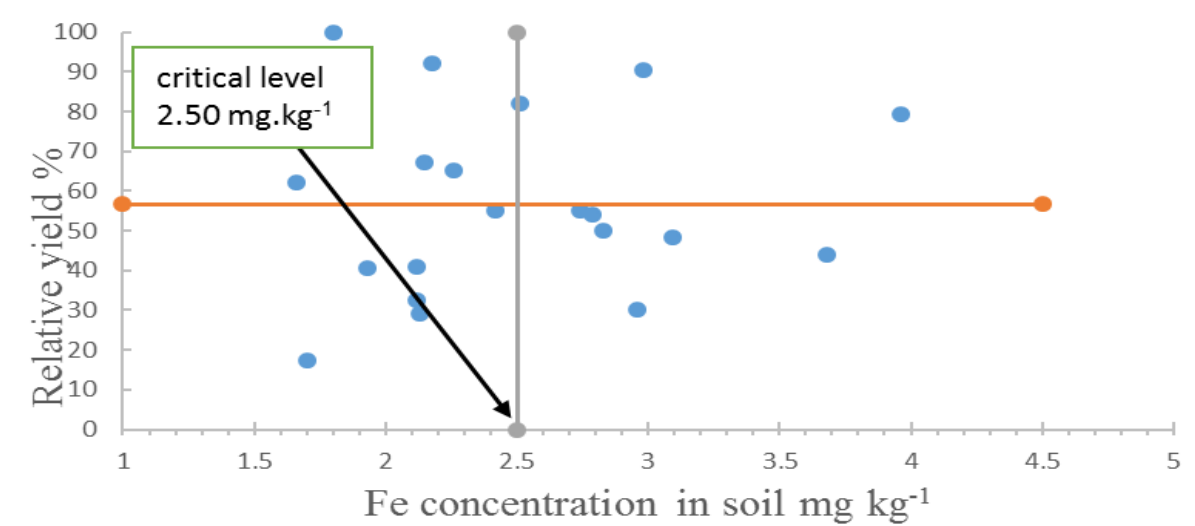

Figure (1a): Critical level of Iron in different soils collected from Sulaimani governorate (graphical method). 


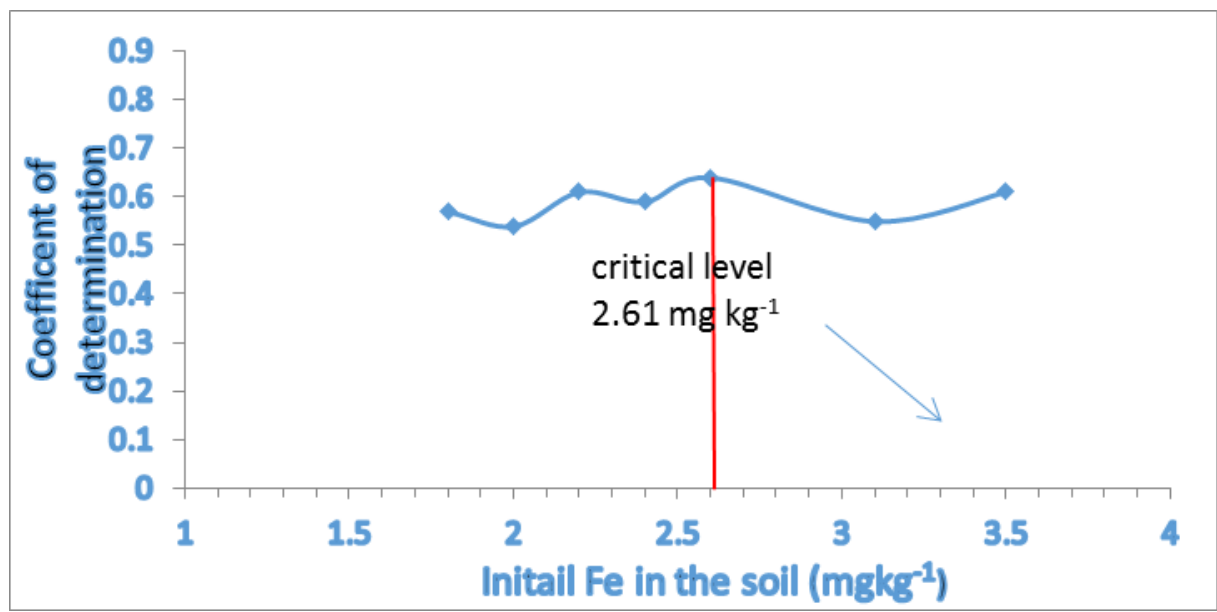

Figure (1b): Critical level of Iron in different soils collected from Sulaimani governorate (statistical method).

It is appear from determined critical level of Iron (figure, $1, a)$ that the concentration of Fe in (11) locations of the studied soils was less than the critical value .

\section{Determination of iron critical level for wheat plant:}

Critical level of Fe was determined by using graphic method (figure ,2a) depending on iron concentration in the plant $\left(\mathrm{mg} \mathrm{kg}^{-1}\right.$ dry weight $)$ and relative yield ( table 6 ), the iron critical level for wheat was (46.55) $\mathrm{mg} \mathrm{kg}^{-1}$ dry matter .The highest $\mathrm{R}^{2}$ (0.63) value was obtained in wheat plant iron at (50.50) $\mathrm{mg} \mathrm{kg}^{-1}$ and therefore the critical limit of iron for wheat plant was (50.50) $\mathrm{mg} \mathrm{kg}^{1}$ by using statistical method or depending on $\left(\mathrm{R}^{2}\right)$ value as shown in (figure, $2 \mathrm{~b}$ ) These results are very close or similar to those recorded by (kumar, 2002 and Meena, 2013). 


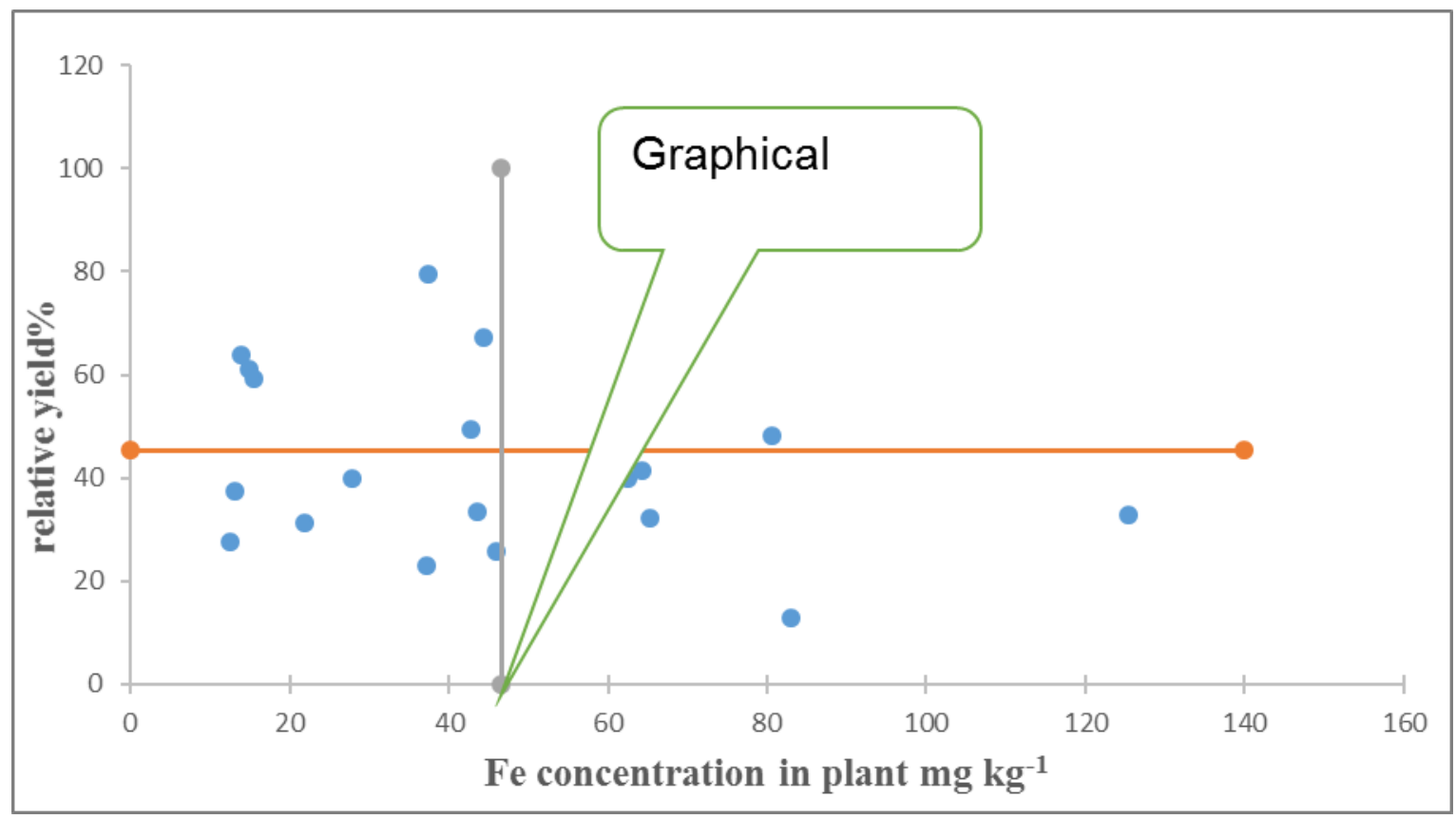

Figure (1a): Critical level of Iron in wheat plants (graphical method).

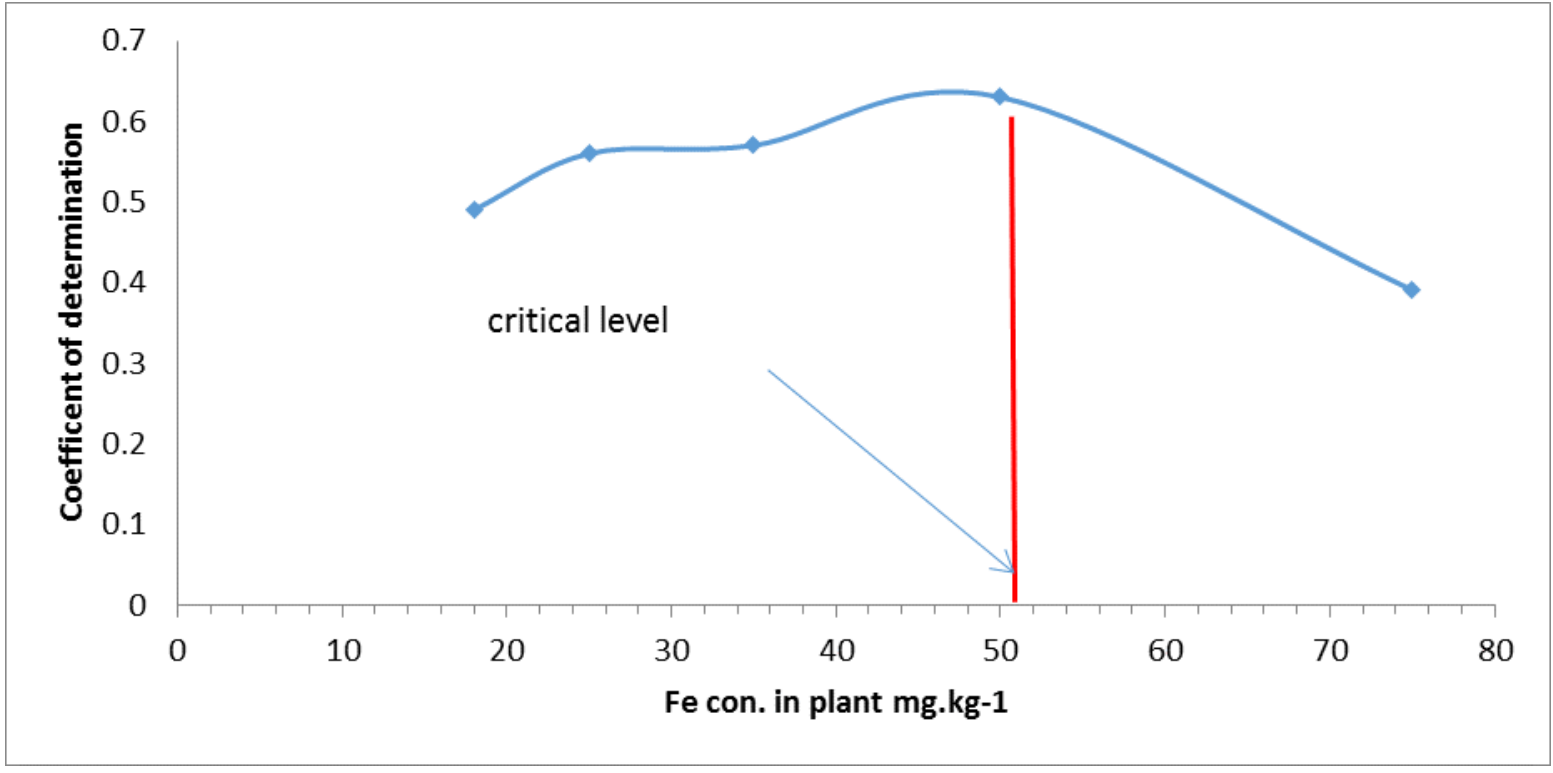

Figure (1b): Critical level of Iron in wheat plants (statistical method) 
Table (6): Effect of locations on iron concentration and relative yield \% (R.Y.\%) of wheat.

\begin{tabular}{|c|c|c|}
\hline Locations & $\begin{array}{l}\text { Fe concentration in } \\
\text { plant } \mathrm{mg} \mathrm{kg}^{-1}\end{array}$ & Relative yield $\%$ \\
\hline Qlyasan & 27.76 & 39.93 \\
\hline Bazyan & 14.97 & 61.16 \\
\hline Bakrajo & 42.80 & 39.84 \\
\hline Serwan & 62.49 & 39.86 \\
\hline Baynjan & 15.44 & 59.14 \\
\hline Halbja & 13.05 & 37.39 \\
\hline Keli & 83.02 & 12.74 \\
\hline SaidSadiq & 13.83 & 63.76 \\
\hline Kalar & 12.56 & 27.57 \\
\hline Kifri & 45.90 & 25.63 \\
\hline Penjwen & 79.64 & 100 \\
\hline Qaldza & 80.51 & 48.26 \\
\hline Ranya & 125.38 & 32.86 \\
\hline Chamchamal & 37.12 & 23.08 \\
\hline Darbandekhan & 21.89 & 31.34 \\
\hline Kanipanka & 37.42 & 79.49 \\
\hline Zrgwez & 64.21 & 41.57 \\
\hline Tasloja & 44.29 & 67.09 \\
\hline Dukan & 43.58 & 33.47 \\
\hline Mawat & 65.21 & 32.33 \\
\hline
\end{tabular}




\section{CONCLUSIONS :}

The statistical method was more accurate than graphical method for estimation $\mathrm{Fe}$ critical level for wheat plant and soil .

The critical level of soil Fe was (2.50) $\mathrm{mgkg}^{-1}$ using graphical method and (2.61) $\mathrm{mgkg}^{-1}$ depending on statistical method for the studied soils in Sulaimani.

The critical level of Fe for wheat crop was (46.55 and 50.50) $\mathrm{mg} \mathrm{kg}^{-1}$ depending on graphical method and statistical method respectively.

\section{RECOMMENDATIONS:}

According to the results of this investigation the following recommendations were recommended:

-Comparison between Iron critical level under field condition and pot -experiment for different plants in Kurdistan region at different growth stages.

-Comparing the Iron critical level in outdoor and indoor experiments.

-Studying the critical level of iron for different plants.

\section{REFERENCES:}

Ahmad, N., Rashid, M., and Vaes, A. G. (1996). Fertilizers and their use in Pakistan: an extension guide (No. 2. ed.).

Baruah, T. C. and Barthakur, H.P. (1999). A text book of soil analysis. Printed at Vishal printers. New- Delhi.

Black, C.A. (1965). Methods of soil analysis. Part2. American Society of Agronomy.lnc. Publishers Madison, Wisconsin. U.S.A.

Cate, R. B., and Nelson, L. A. (1971). A simple statistical procedure for partitioning soil test correlation data into two classes. Soil Science Society of America Journal, 35(4): 658-660.

Cate, R. B., and Nelson, L. A. (1965). A rapid method for correlation of soil test analyses with plant response data. NC State University Agricultural Experiment Station.

Dahnke, W. C. and Olson, R. A. (1990). Soil test correlation, calibration, and recommendation. Pp 45-71., Madison, Wisconsin 1990. 
Darwesh, D. A. and Esmail A. O. (2008). The role of supplemental irrigation and fertilizer treatments on yield componentof wheat. Mesopotamia Journal of Agriculture .36 (1): 30-38.

Hama-Amin, C.O.(2012).Using differend methods to determine critical level of potassium for wheat plant (Triticum durum L.)in Erbil plain soils .Univ. of Salahaddin, Erbil ,College of Agriculture.

Halverson, A.R. (2001). Soil sampling accuracy. Manual 19. Pacific. North West Fertilizer Conference .Pullman. Washington.

Havlin, J.L., Tisdale, S.L., Nelson W.L., and Beaton J.D (2014). Soil fertility and nutrient Management: an introduction to nutrient management. ( $8^{\text {th }}$ edt) Pearson (p 505), Upper Saddle River, New Jersey. U.S.A.

Havlin, J. L., and Soltanpour, P. N. (1981). Evaluation of the NH4HCO3-DTPA soil test for iron and zinc. Soil Science Society of America Journal, 45(1): 70-75.

Hodgson J.M. (1976). Soil survey field handbook. Technical monograph (5): Pp5657.printed in England.

Jackson, M. L. (1973). Soil chemical analysis. Prentice Hall, Inc. London.

Jarallah, Kh. A. (2005). Evaluation of iron fertility status and response of wheat in some of Mesopotamian plain soils. PhD Thesis, Dept. of Soil and water Science, College of Agriculture, Baghdad University.

Khdir, S.A. (2017) The role of some soilphysicochemical properties in limiting potassium critical level for Bitwen plain soils -Kurdistan region.MSC. thesis Univ. of Salahaddin, College of Agriculture.

Kumar, M. (2002). Effect of manganese and iron on the soil properties, nutrient uptake and performance of wheat (L.) and barley (L.) M.Sc. (Ag.) Thesis, Maharana Pratap University of Agriculture and Technology, Udaipur (Raj.).

Lindsay, W. L., and Schwab, A. P. (1982). The chemistry of iron in soils and its availability to plants. Journal of Plant Nutrition, 5(4-7):821-840.

Loeppert, R. H. and Iskeep, W. P. (1996). Iron methods of soil analysis, Part 3, chemical methods, C.F: Sparks, D. L., Page, A. L., Helmke, P. A., Loeppert, R. H., Soltanpour, P. N., Tabatabai, M. A., and Sumner, M. E. (1996). Methods of soil 
analysis. Part 3-Chemical methods. Soil Science Society of America Inc., Pp. 437474.

Meena, R.S., Mathur, A.K. and Sharma, S.K. (2013). Determination of critical limit of iron for wheat in soils of sub-humid southern zone (IV-B) of Rajasthan. International Journal

Mohsin, H.A.A, (2013). Effect Different Levels of Chelated Iron on the Growth and yield of Wheat (Triticum aestivum L.) under Thi- Qar and Al-Muthanaa conditions. International Journal of Science and Research, 4(9):1741-1743.

SAS Institute, (2001). The SAS system for Windows, The SAS Inst. Cary, NC.

Shekh bzayni, I. T. A. (2005). The critical level of phosphorus for wheat (Triticum durum L.) in Arbil plain soils. MSc. Thesis Univ. of Salahaddin,Erbil ,College of Agriculture.

Sims, J.T and Johnson, G.V. (1991). Micronutrient soil tests, C.F: Mortvedt, J.J., Cox, F.

R., Shuman L. M., and Welch, R. M. (2 ${ }^{\text {nd }}$ edt.), (1991). Micronutrients in Agriculture. Soil

Science Society of America Journal. 4: 427-476.

Soltanpour, P. A., and Schwab, A. P. (1977). A new soil test for simultaneous extraction of macro-and micro-nutrients in alkaline soils 1. Communications in Soil Science and Plant Analysis, 8(3):195-207.

White, P. J., and Broadley, M. R. (2009). Bio fortification of crops with seven mineral elements often lacking in human diets-iron, zinc, copper, calcium, magnesium, selenium and iodine. New Phytologist, 182(1): 49-84.

Whitney, D. A. (1988). Micronutrient soil test zinc, iron, manganese and copper. Pp.2022. C.F: Dahnke, W. C. (1990). Recommended chemical soil test Procedures for the North Central Region. North Dakota Agric. Exp. Stn. Bull, 499. Review. 